\title{
Neutralidade da Rede, Filtragem de Conteúdo e Interesse Público: Reflexões sobre o Bloqueio do Site YouTube no Brasil
}

\author{
Carlos Affonso Pereira de Souza' \\ Pedro de Paranaguá Moniz ${ }^{2}$ \\ Sérgio Branco Vieira Junior ${ }^{3}$ \\ "Toda imagem está fadada à ampliação" \\ Gaston Bachelard
}

\section{Ampliação da imagem, ampliação do litígio}

A filmagem escondida de cenas íntimas entre uma famosa modelo brasileira e seu namorado na praia de Cádiz, na Espanha, tornou-se, no início do ano de 2007, um dos assuntos mais debatidos na imprensa nacional. Esse seria mais um típico caso de responsabilidade civil por violação a direitos da personalidade, especialmente a imagem, se não fosse por um inusitado motivo: ao ingressar com medida judicial para obrigar diversos websites na Internet que hospedavam o vídeo a retirá-lo de exibição, a decisão judicial prolatada resultou no bloqueio do acesso de um dos websites mais visitados da Internet mundial para usuários brasileiros. Não apenas a imagem em questão havia sido ampliada. O litígio,

\footnotetext{
Doutorando e Mestre em Direito Civil na Universidade do Estado do Rio de Janeiro (UERJ). Professor dos cursos de graduação e pós-graduação da FGV Direito Rio e da Pontifícia Universidade Católica (PUC-Rio). Coordenador Adjunto do Centro de Tecnologia e Sociedade (CTS) da FGV Direito Rio. Membro da Comissão de Direito Autoral e Entretenimento da OAB/RJ.

2 Mestre em Direito da Propriedade Intelectual, University of London. Professor dos cursos de graduaçāo e pós-graduação da FGV Direito Rio e do Mestrado Profissional em Propriedade Intelectual do Instituto Nacional da Propriedade Industrial (INPI). Líder de Projetos do Centro de Tecnologia e Sociedade (CTS) da FGV Direito Rio.

3 Doutorando e Mestre em Direito Civil na Universidade do Estado do Rio de Janeiro (UERJ). Professor dos cursos de pós-graduaçāo da FGV Direito Rio. Líder de Projetos do Centro de Tecnologia e Sociedade (CTS) da FGV Direito Rio.
} 
então particular, se transformara em questão de interesse público, pois o direito de acesso ao conhecimento, cultura e entretenimento de milhōes havia sido restringido indevidamente.

A repercussāo da medida judicial que ocasionou o bloqueio do website YouTube foi proporcional ao seu volume de acesso. A imprensa nacional e internacional deu destaque à matéria, ${ }^{4}$ tornando-se comuns associações entre o Brasil e países que oficialmente censuram o conteúdo de sua rede mundial de computadores.

Em poucos dias o embaraço causado pelo bloqueio do website foi desfeito através de nova decisão do juiz encarregado do caso, mas as repercussões de uma decisão inédita na jurisprudência nacional ainda serão sentidas nos casos vindouros sobre os limites da liberdade de expressão, a responsabilidade civil dos provedores de serviços e a possibilidade de filtragem de conteúdo na Internet.

A literatura jurídica e a jurisprudência nacional já se pronunciaram diversas vezes sobre a colisão entre liberdade de expressão e direitos da personalidade. A extensão da tutela do direito à imagem, a redução na esfera de privacidade das pessoas notórias e a retratação de pessoas em locais públicos já foram objeto de suficientes reflexōes. E o caso a seguir narrado seria apenas mais um episódio no vasto rol de eventos levados à discussão judicial nesses termos se não fosse pela decisão aqui debatida. Ao propiciar o bloqueio integral de um website por conta da exibição de um único vídeo (dentre milhares de outros exibidos pelo mesmo site), a decisão judicial ultrapassou as fronteiras entre o interesse das partes envolvidas no litígio e o interesse da coletividade; ultrapassou, pode-se mesmo dizer, a tradicional linha divisória entre o Direito Público e o Privado.

Se a teoria e a prática da responsabilidade civil são insuficientes para compreender a extensão do presente caso, o instrumento de ponderação na colisão entre direitos fundamentais também não açambarca integralmente os questionamentos aqui trazidos. É na união desses dois instrumentais, somados a considerações de natureza tecnológica, que se pode buscar um melhor entendimento sobre a decisão tomada e as suas repercussões.

Nessa direção, o escopo do presente artigo é refletir sobre algumas das derivaçōes mais importantes do caso a seguir narrado. Como norte das discussões aqui tratadas escolheram-se os temas da neutralidade da rede, a filtragem de conteúdo e a extensão dos interesses públicos aplicáveis ao caso.

\section{Breve histórico dos fatos}

Em setembro de 2006 a modelo Daniela Cicarelli e seu namorado, Renato Malzoni Filho, ingressaram com ações judiciais contra a YouTube Inc., empresa que operava o website norte-americano YouTube (posteriormente adquirido pela

\footnotetext{
+ BBC Brasil: Disputa entre YouTube e Cicarelli repercute no exterior. Disponivel em: <http://www. estadao.com.br/arteelazer/variedades/noticias/2007/jan/05/297.htm>. Acesso em: 4 fev. 2007.
} 
Google), as Organizaçōes Globo e o Internet Group (iG), tendo por objeto a retirada do vídeo em questão dos websites administrados pelos réus e o pedido de indenização pelos danos causados aos autores por conta de sua exibição. Por decisão do juiz Gustavo Santini Teodoro, da 23 $3^{\text {a }}$ Vara Cível da Capital (São Paulo), os processos deveriam correr em regime de segredo de justiça, uma vez que a notoriedade da autora levaria à grande procura dos autos nas serventias cartorárias. ${ }^{5}$ Essa decisão terminou por dificultar uma análise mais aprofundada sobre os detalhes dos processos movidos pelos autores, tendo sido revelado ao público em geral apenas as decisōes em seguida relatadas.

Os três réus operam websites de grande audiência na Internet brasileira. Entre os três, contudo, existe uma grande diferença: o conteúdo do website YouTube não é diretamente gerado por uma equipe editorial, mas sim construído pelo material inserido no website pelos seus milhares de usuários. O YouTube é um website que hospeda vídeos das mais diferentes espécies na rede mundial de computadores, estimulando a troca de informaçōes e gerando visibilidade para materiais que não encontrariam espaço em websites dos canais de mídia tradicionais.

Ao apreciar o caso em primeira instância, o Juízo da $23^{\text {a }}$ Vara Cível da Capital negou o pedido de retirada do vídeo dos websites operados pelas empresas-ré. Em sede de agravo de instrumento, por sua vez, foi concedida liminar pelo Tribunal de Justiça de São Paulo, determinando a retirada do vídeo dos websites em questão, sob pena de multa diária de $\mathrm{R} \$ 250$ mil.

Surge aqui o primeiro impasse na análise da efetividade de uma decisão judicial que comande a filtragem de conteúdo no ambiente de Internet: a existência de uma dificuldade técnica no cumprimento da decisão quando o conteúdo do website em questão não é construído a partir de escolhas editoriais de funcionários ou colaboradores das empresas ré, mas sim através de upload direto de conteúdo por parte dos mais diversos usuários.

Dessa forma, o cumprimento da decisão judicial pela YouTube Inc. tornou-se um assunto delicado. Para garantir que o mencionado vídeo não fosse disponibilizado pelo website YouTube nāo bastava retirar de exibição aqueles arquivos que lá já estavam hospedados, pois a qualquer momento qualquer usuário poderia inserir novamente o conteúdo impugnado. Em situações como a narrada, é comum recorrer-se ao mecanismo de bloqueio de expressōes que identificam o vídeo, como o nome da pessoa envolvida ou o local de filmagem. Essa solução também apresenta uma série de percalços, podendo-se, apenas para mencionar alguns, apontar a existência de homônimos e o bloqueio de conteúdos que nenhuma relação guardam com o caso em questão.

Adicionalmente, os usuários do website poderiam, ao perceber o bloqueio de certas expressōes, inserir o mesmo vídeo apenas alterando as expressões que o identificam ou mesmo o nome do arquivo em si. O resultado é um só: para garan-

\footnotetext{
Consultor Jurídico: O namoro do ano - Justiça confirma veto ao vídeo de Cicarelli na internet. Disponivel em: <http://conjur.estadao.com.br/static/text/48727,1 >. Acesso em: 4 fev. 2007.
} 
tir efetividade à decisão judicial não basta o recuso aos mecanismos tecnológicos atualmente disponíveis; é necessário uma pessoa que faça uma espécie de vigilância constante sobre o conteúdo do website, retirando do ar qualquer material que eventualmente venha a ser inserido pelos seus usuários. Esse tipo de medida será objeto de comentários nos tópico seguintes.

Como, mesmo após a publicação da decisão judicial, o conteúdo impugnado continuava a ser exibido no website YouTube, solicitaram os autores, conforme noticiado na imprensa, o bloqueio do website como um todo, uma vez que a empresa-ré não havia cumprido com a determinação judicial anterior. ${ }^{6}$

Ao analisar esse novo pedido, foi proferida no dia 2.1.2007, pelo Desembargador Ênio Santarelli Zuliani, integrante da $4^{a}$ Câmara de Direito Privado do Tribunal de Justiça do Estado de São Paulo, uma liminar no agravo de instrumento $\mathrm{n}^{\circ}$ 488.184-4/3 que pretensamente determinava a retirada do ar integral do website YouTube. Apoiada em laudo técnico, a decisão determinaria que as cinco empresas que operam os backbones da Internet brasileira bloqueassem o acesso de usuários nacionais ao referido website. ${ }^{7}$

Conforme consta em extrato da decisão, divulgado pelo próprio Tribunal, a mesma determinou que as empresas que operam os backbones da Internet brasileira "promovam a colocação do filtro na solicitação de acesso ou na entrada da resposta no website americano [YouTube], de forma a inviabilizar, por completo, o acesso, pelos brasileiros, ao filme do casal."

A redação dúbia da decisão comentada gerou resultados diversos, pois se para alguns ela determinava apenas o bloqueio do acesso ao vídeo impugnado, para outros ela teria mesmo o condão de retirar não a exibição do vídeo, mas sim o acesso ao website por completo. E a única forma de realizar esse "desligamento" de um website estrangeiro da Internet brasileira é através de um bloqueio realizado nos backbones.

Segundo informações divulgadas pela imprensa, duas das cinco empresas que operam os backbones da Internet nacional efetivamente promoveram o bloqueio do website YouTube, tornando-o inacessível para milhões de usuários. Estima-se que cerca de $25 \%$ dos usuários conectados à Internet no Brasil, o que corresponde a mais de 5 (cinco) milhões de pessoas, ficaram sem acesso ao referido website. ${ }^{8}$

Em decorrência da repercussão gerada na imprensa e nos mais diversos fóruns de discussão na Internet, a assessoria de imprensa do Tribunal divulgou nota, no dia 4.1.2007, esclarecendo que em momento algum teria sido determinado o

6 IDG Now!: Justiça de SP nega que mandou tirar YouTube do ar. Disponível em: <http://idgnow. uol.com.br/internet/2007/01/04/idgnoticia.2007-01-04.0064595137/IDGNoticia_view>. Acesso em: 4 jan. 2007.

- Backbones são chamados de espinhas dorsais da rede mundial de computadores, uma vez que sāo os servidores responsáveis pelo tráfego de informação entre os websites estrangeiros e os nacionais.

8 UOL: Brasil Telecom e Telefonica bloqueiam acesso ao YouTube. Disponível em: <http://tecnologia.uol.com.br/ultnot/2007/01/09/ult4213u3.jhtm>. Acesso em: 9 jan. 2007. 
bloqueio do website YouTube. ${ }^{9}$ Logo em seguida, no dia 9.1.2007, o Desembargador Ênio Santarelli Zuliani proferiu novo despacho, explicitando que "não foi determinado o bloqueio do sinal do site YouTube". A mesma decisão ainda determinou o restabelecimento do "sinal do YouTube, solicitando que as operadoras restabeleçam o acesso e informem ao Tribunal as razões técnicas da suposta impossibilidade de serem bloqueados os endereços eletrônicos".

Ao justificar os motivos que teriam levado à elaboração de novo despacho, esclarecendo o alcance de sua decisão, o referido Desembargador explicitou que a decisão anterior "está gerando uma série de comentários, o que é natural em virtude de ser uma questão pioneira, sem apoio legislativo". Esse trecho do despacho merece destaque por tornar evidente uma das questões mais importantes envolvidas no presente debate: a ausência de parâmetros a guiar o julgador em ações judiciais envolvendo a responsabilidade civil de provedores de serviços na Internet e a dificuldade em se adequar a técnica da decisão judicial à prática da evolução tecnológica.

Em atençāo ao último despacho, o acesso ao website YouTube foi restaurado. ${ }^{10}$ A polêmica gerada pelo seu bloqueio e os efeitos da respectiva decisão judicial, por sua vez, ainda repercutem nas discussões jurídicas especializadas e terão renovada intensidade a cada nova ação judicial semelhante a ser apreciada no futuro.

\section{Análise do caso concreto}

Duas questões podem ser inicialmente abordadas para a análise do caso aqui comentado. Inicialmente pode-se analisar a decisão do agravo de instrumento que determinou a retirada do vídeo impugnado dos websites operados pelos réus. Essa decisão está baseada na necessidade de se obstar a exibição do vídeo de imediato, sendo posteriormente averiguada a procedência do pleito indenizatório. Os parâmetros utilizados pelos julgadores podem ser examinados à luz de recentes decisões judiciais sobre o tema da responsabilidade civil por ofensas ao direito de imagem e à privacidade.

Outro ponto de relevo para a análise do presente caso é o entendimento sobre a aplicação de direitos fundamentais, previstos na Constituição Federal, para o deslinde de litígios surgidos em relações entre particulares. Nesse sentido, fazse ainda necessário investigar como o princípio da proporcionalidade pode ser um instrumental valioso para mensurar as conseqüências de uma decisão judicial como a tomada no caso em questão.

\footnotetext{
IDG Now!: Justiça de SP nega que mandou tirar YouTube do ar. Disponivel em: <http://idgnow. uol.com.br/internet/2007/01/04/idgnoticia.2007-01-04.0064595137/IDGNoticia_view $>$. Acesso em: 4 fev. 2007.

10 IDG Now!: Brasil Telecom e Telefônica liberam acesso ao YouTube no Brasil. Disponivel em: $<$ http://idgnow.uol.com.br/internet/2007/01/09/idgnoticia.2007-01-09.5384975768/IDGNoticia_ view >. Acesso em: 9 jan. 2007.
} 
Sendo assim, a análise do caso concreto passará de início por consideraçōes sobre responsabilidade civil para o exame da decisão proferida em sede do agravo de instrumento, valendo-se então de instrumentais da teoria constitucional para refletir sobre a decisão posterior que, pretensamente, teria o escopo de retirar o acesso não apenas ao vídeo impugnado, mas ao website YouTube como um todo.

\section{I Algumas consideraçōes sobre responsabilidade civil}

A decisão do agravo de instrumento $n^{\circ} 472738-4$, tomada por maioria na Quarta Câmara de Direito Privado do Tribunal de Justiça de São Paulo, traz uma série de elementos relevantes para o debate do caso em tela. Como sabido, a referida decisão ordenou a retirada do vídeo impugnado dos websites operados pelas rés, atendendo ao pedido de tutela inibitória formulado pelos autores. Ainda que não se pronunciando sobre a existência ou não de lesão aos direitos da personalidade a legitimar o pleito indenizatório, a Câmara entendeu que a veiculação do vídeo até o desfecho do processo judicial poderia acarretar em graves prejuízos para a imagem, honra e privacidade do casal.

A ementa do acórdão, cuja relatoria coube ao Desembargador Ênio Santarelli Zuliani, assim ficou redigida:

"Pedido de antecipação de sentença por violação do direito à imagem, privacidade, intimidade e honra de pessoas fotografadas e filmadas em posiçōes amorosas em areia e mar espanhóis - Tutela inibitória que se revela adequada para fazer cessar a exposição dos filmes e fotografias em web-sites, por ser verossímil a presunção de falta de consentimento para a publicação [art. 273, do CPC] - Interpretação do art. 461, do CPC e 12 e 21 , do CC - Provimento, com cominação de multa diária de $\mathrm{R} \$ 250.000,00$, para inibir transgressão ao comando de abstenção."11

Em primeira instância, o pleito pela retirada preventiva do vídeo dos websites operados pelas rés foi declarado improcedente "sob o fundamento de que não haveria ato ilícito na captação de imagens de banhistas que se beijam e trocam ousadas carícias em público, circunstância que excluiria ofensa a 'direito à imagem ou desrespeito à honra, à intimidade ou à privacidade dos autores".

O relator do acórdão, contudo, ponderou que se é certo que o direito de imagem sofre temperamentos, não existiria qualquer exceção legítima que amparasse a captura e exibição do vídeo impugnado. Foram fatores decisivos para a relatoria do voto vencedor o fato do vídeo ter sido produzido de forma clandestina, ou seja, sem autorização de seus protagonistas, e a repercussão que a sua veiculação estaria causando na vida pessoal e profissional dos autores.

\footnotetext{
TJSP, Agr. 472738-4; rel. Des. Ênio Santarelli Zuliani; j. em 28.9.2006.
} 
Parece existir consenso na doutrina e jurisprudência, tanto nacional como internacional, no sentido de que a regra geral para a exploração da imagem de terceiro é a existência de alguma forma de consentimento ou autorização. Se o consentimento, seja expresso ou tácito, se faz necessário para retirar o espectro de ilicitude da gravação, fotografia, filmagem etc., é válido afirmar que existe também uma série de circunstâncias nas quais a imagem poderá ser utilizada sem a autorização de seu titular, ou mesmo contra a sua vontade.

É relevante ater-se inicialmente na questão da utilização da imagem contra a vontade do seu titular. Pode parecer incoerente afirmar tal possibilidade, uma vez que o direito à imagem foi construído como um direito da personalidade, como um verdadeiro direito subjetivo que o seu titular possuiria para impedir intrusões no exclusivo controle dos seus aspectos físicos e comportamentais.

Não é raro encontrar entendimentos que prezam o caráter absoluto dos chamados direitos da personalidade. Todavia, afirmar que os direitos da personalidade são absolutos jamais poderá significar que os mesmos estão isentos de toda e qualquer ponderação com interesses outros. $O$ direito à imagem, por seu turno, freqüentemente coloca-se em situação de colisão com o direito à informação e a liberdade de expressão. Decidir litígios que envolvem tais direitos, geralmente contrapostos, necessita de um instrumental que transcende mesmo as clássicas definiçōes de direito privado, especialmente a de direito subjetivo, para encontrar um início de solução na teoria constitucional e na ponderação de interesses, temas abordados no próximo tópico.

Sendo assim, o direito à imagem deve sempre ser analisado à luz de outros interesses que poderão fazer com que a sua tutela não seja aplicável ao caso concreto, tornando possível a utilização de imagem de terceiro de modo inconsentido.

Se uma imagem desagrada a uma figura pública, mas a sua veiculação esclarece um fato policial devidamente investigado, não haveria motivos para permitir a sua utilização? Se a imagem de uma pessoa foi utilizada sem a sua autorização, mas ela é apenas elemento acessório da foto, irrelevante para o contexto que se quer retratar, não haveria motivos para permitir a sua utilização? E se uma imagem não é autorizada por seu protagonista, mas o mesmo encontrava-se em local público e, por ser figura pública, desperta atenção igualmente pública, também não haveria motivos para permitir a sua utilização?

A última questão remete justamente aos fatos que ocasionaram o caso aqui comentado. A modelo, protagonista do vídeo impugnado, é figura notória e, vale dizer, não apenas no Brasil, mas também de certa forma na Espanha, país onde a sua imagem foi capturada, por conta de relacionamento amoroso com jogador de futebol então em atividade naquele país. Dessa forma, existe aqui uma primeira exceção geralmente levantada pela jurisprudência nacional em casos de uso pretensamente indevido da imagem, ou de invasōes à privacidade, qual seja, a notoriedade da pessoa retratada. 
Adicionalmente, o vídeo impugnado retrata pessoa notória não em seu ambiente de convívio privado, reservado, mas sim em pleno local de freqüência pública. A presença de pessoa notória nas areias de uma praia pública, por sinal, é um exemplo acadêmico sobre exposição da intimidade e conflitos derivados da colisão entre imagem/privacidade e liberdade de informação e de expressão.

Seria ilícita, parece restar poucas dúvidas, a captura da imagem de terceiro dentro de seu ambiente particular, como a sua residência, por exemplo. Ao se expor aos olhares de terceiros, ao freqüentar locais públicos, a pessoa notória atrai naturalmente a atenção daqueles que estão ao seu redor. Nas últimas décadas, doutrina, legislação e jurisprudência trataram de traçar os limites entre a curiosidade ilícita, que afronta a intimidade pessoal, e uma certa permissividade concedida aos anseios de uma sociedade tipicamente voyeurista.

O estado atual dessa constante evolução do pensamento jurídico se caracteriza pela eleição de exceções ao direito "absoluto" de imagem, sendo a captura e utilização da imagem de terceiro em local público uma das mais constantemente afirmadas. Caso se tenha então uma pessoa notória retratada em local público, tratase de circunstância em que duas das mais citadas exceçōes podem ser aplicadas; trata-se de uma exceção célebre.

Em caso bastante semelhante ao presente, o Superior Tribunal de Justiça já decidiu que estampar em jornal de grande circulaçāo foto de mulher que fazia topless em praia pública não gera para a mesma o direito de indenização. Muito ao reverso, se a protagonista da foto optou por abrir mão da sua intimidade, o que, como titular do direito, Ihe é facultado, a captura da imagem e sua utilização tornou-se mera conseqüência. A sua própria conduta propiciou tal encadeamento de eventos.

O mencionado acórdão do Superior Tribunal de Justiça possui a seguinte ementa: blico.

“Direito Civil. Direito de Imagem. Topless praticado em cenário pú-

Não se pode cometer o delírio de, em nome do direito de privacidade, estabelecer-se uma redoma protetora em torno de uma pessoa para tornála imune de qualquer veiculação atinente a sua imagem.

Se a demandante expõe sua imagem em cenário público, não é ilícita ou indevida sua reprodução pela imprensa, uma vez que a proteção à privacidade encontra limite na própria exposição realizada." 12

A decisão do Tribunal de Justiça de Santa Catarina, que havia igualmente negado o pleito indenizatório em segunda instância, também se pautou pelo fato de que a protagonista da foto havia livremente optado por fazer topless nas areias de uma praia, local público e de freqüência coletiva. Como ressalta o referido acórdão:

12 STJ, REsp n² 595600/SC, rel. Min. Cesar Asfor Rocha; j. em 18.3.2004. 
"A imagem das pessoas constitui uma forma do direito à intimidade. Quem quer preservar sua honra e sua intimidade não expōe os seios para deleite da multidão. Se a embargada resolveu mostrar sua intimidade às pessoas deve ter maturidade suficiente para suportar as conseqüências de seus atos e não atribuir à imprensa a responsabilidade pelo ocorrido.

É importante salientar que a praia estava cheia e era feriado. A fotografia não foi obtida de recinto ou propriedade particular, ou de ambiente exclusivamente privado. Mas muito pelo contrário, o fotógrafo simplesmente registrou o que estava à mostra para todos os presentes na Praia Mole, naquele momento."

É importante destacar que se o precedente acima referido gerou uma decisão contrária à indenização pleiteada por pessoa anônima em local público, o caso aqui comentado, por sua vez, oferece fundamentos muito mais robustos para o indeferimento do pedido autoral, dado que a pessoa notória, como já ressaltado, desperta naturalmente a atenção do público em geral, sofrendo uma certa redução na sua esfera de privacidade.

Poderia-se então opor a esse entendimento o fato de que as cenas constantes do vídeo impugnado possuem um caráter muito mais íntimo do que aquelas retratadas pelo jornal catarinense. Esse argumento, contudo, termina por oferecer subsídios não para a defesa da privacidade, mas justamente ao contrário, pois, dadas as circunstâncias, ele apenas demonstra a falta de cautela da pessoa notória com relação à sua exposição pública.

Uma vez superadas as questōes atinentes estritamente à responsabilização civil, faz-se necessário adentrar na discussão sobre os direitos fundamentais envolvidos no caso, a sua eventual ponderação, e a proporcionalidade da medida judicial que, após solicitar a retirada do vídeo, determinou o bloqueio do acesso ao website YouTube.

\subsection{Direitos fundamentais e relações privadas}

As normas constitucionais gozam de posição privilegiada no ordenamento jurídico. Para além da famosa construção doutrinária sobre a disposiçāo das diversas categorias de normas jurídicas de acordo com sua hierarquia, situando-se as normas constitucionais no ápice da pirâmide, é importante perceber para o presente debate que a Constituição é o fundamento de validade das demais normas, construindo-se, a partir dela, a sua orientação interpretativa.

A partir do reconhecimento do papel desempenhado pelo texto constitucional no ordernamento jurídico nacional, diversos instrumentais foram criados para interpretar e aplicar as suas disposições. Nesse particular, o entendimento pela aplicação direta das normas constitucionais nas relaçōes privadas merece destaque. 
Se, por um lado, as normas constitucionais se aplicam nas relações travadas entre particulares, é relevante destacar que os diplomas mais diretamente ligados à regulamentação das atividades privadas também sofrem essa influência, devendo ser lidos à luz do texto constitucional. Uma das derivações mais notórias dessa mudança na tendência interpretativa foi o reconhecimento de um verdadeiro Direito Civil Constitucional, o qual "consiste em um discurso de defesa dos princípios constitucionais e, especificamente, da sua direta e imediata aplicação a todas as relações jurídicas - aí incluídas as relações tipicamente de natureza civil, travadas entre os particulares". ${ }^{13}$

Contra a referida leitura das relações jurídicas privadas à luz da Constituição foi levantada uma série de objeçōes. Segundo Gustavo Tepedino, as referidas objeçōes poderiam ser resumidas a quatro críticas principais.

A primeira das críticas estaria centrada na vocação do texto constitucional para o estabelecimento dos modelos de organização dos poderes estatais. Dessa forma, o texto constitucional seria destinado não à regulação direta de relações jurídicas entre particulares, mas apenas ao legislador infra-constitucional.

A segunda objeção estaria focada na "baixa densidade normativa dos princípios constitucionais, cuja aplicação às relações privadas propiciaria uma excessiva discricionariedade do magistrado na solução de concretos conflitos de interesse". ${ }^{14}$

A própria estabilidade da dogmática do Direito Civil que, obedecendo a seu curso constante desde os primórdios romanos, faz avançar os estudos e a aplicação das normas nas relações entre particulares seria o objeto da terceira crítica. Segundo esse entendimento, é a atuação do legislador ordinário que impede que a natural instabilidade do texto constitucional, resultado da complexa soma de interesses presentes na Assembléia Constituinte, perturbe o regramento das relaçōes privadas.

Por fim, a quarta crítica considera a aplicação do texto constitucional a uma invasão desmedida nos espaços da vida privada, pois os limites de aplicação dos direitos fundamentais e demais dispositivos constitucionais não estão necessariamente dispostos na própria Constituição. Para relações cujo parâmetro sempre havia sido a dicotomia lícito/ilícito, a dinâmica complexa de interpretação e aplicação do texto constitucional poderia representar abusos futuros.

É evidente que, ainda que respeitáveis, tais críticas podem ser refutadas com o argumento de que foram erigidas levando-se em conta a realidade da era das codificaçōes, sobretudo os preceitos prevalecentes no século XIX. A pouca utilidade da dicotomia entre Direito Público e Direito Privado reforça a necessidade de aplicação do texto constitucional nas relações privadas, podendo-se mencionar vários institutos que desafiam a classificação baseada nessa ortodoxa separação. ${ }^{15}$

\footnotetext{
13 Teresa Negreiros. Teoria do contrato. Rio de Janeiro: Renovar, 2002. p. 67.

14 Gustavo Tepedino. Editorial da Revista Trimestral de Direito Civil, Rio de Janeiro: Editora Padma, v. 14, abril/junho de 2003.

15 Idem. Ibidem.
} 
Tomando-se como ponto de partida a aplicação das normas constitucionais nas relações entre particulares e a leitura do Código Civil à luz da Constituição, deve-se ainda retirar um último óbice para a análise do caso aqui comentado: trata-se da suposta obsolescência desse instrumental com a entrada em vigor de um novo Código Civil. Para esse entendimento, o Código Civil em vigor, "sendo posterior à Constituição Federal, restauraria a unidade codificada do direito privado, tornando desnecessária a interpretação constitucionalizada dos institutos de direito civil". ${ }^{16}$ Diante dessa concepção, as normas constitucionais voltariam a ser mero limite ao legislador e meio de integração do sistema, tendo perdido seu caráter orientador do Direito Civil e das relaçōes entre particulares.

$O$ referido entendimento pode, todavia, ser percebido como um erro metodológico, pois reedita a dicotomia superada entre o Direito Público e o Direito Privado. O chamado Direito Civil Constitucional não se restringe a uma simples técnica interpretativa das normas de Direito Privado a partir das normas constitucionais. Como refere novamente Gustavo Tepedino, trata-se de "valores expressos pelo legislador constituinte que, extraídos da cultura, da consciência social, do ideário ético e da noção de justiça presentes na sociedade, consubstanciam-se em princípios, os quais devem informar o sistema como um todo e, especialmente, o Código Civil". ${ }^{\text {" }}$

Adicionalmente, o próprio Código Civil apresenta-se intrinsecamente distinto de seu anterior. Como já foi observado, "a finalidade, hoje, de um Código Civil, é menos 'regulativa' e mais 'ordenatória', no sentido de 'pôr ordem', ordenar as relaçōes interpretativas segundo certas técnicas e certos valores em regra postos como diretrizes, garantias e direitos fundamentais na Constituição". ${ }^{18}$

Dessa forma, a relação entre Direito Civil e Direito Constitucional precisa ser repensada e trabalhada a partir de uma matriz que permita ao intérprete e aplicador do Direito o manejo de um instrumental único e eficiente para a solução de situações cada vez mais complexas. Justamente por isso, pode-se afirmar que "a ordem constitucional é hoje fonte reguladora tanto do poder político como da sociedade civil. [...] Nessa perspectiva, não há mais limites precisos que separam direito constitucional e direito privado, não sendo possível concebê-los como comportamentos estanques, como mundos separados, impermeáveis, governados por lógicas diferentes". ${ }^{19}$

\footnotetext{
Idem. Ibidem.

Idem. Ibidem.

Judith Martins-Costa. Os direitos fundamentais e a opção culturalista do novo Código Civil, in Ingo Wolfgang Sarlet (Org.). Constituição, direitos fundamentais e direito privado. Porto Alegre: Livraria do Advogado, 2003, p. 77.

is Jane Reis Gonçalves Pereira. Apontamentos sobre a aplicaçāo das normas de direito fundamental nas relaçōes jurídicas entre particulares", in Luis Roberto Barroso (Org.). A nova interpretaçāo constitucional: ponderaçāo, direitos fundamentais e relaçóes privadas. Rio de Janeiro: Renovar, 2003, p. 120.
} 
De fato, se a superação da dicotomia entre Direito Público e Direito Privado já parece ser tema de aparições recorrentes na doutrina nacional e internacional, ${ }^{20}$ igual destino pode ser apontado com respeito à distinção hermética sobre as áreas de atuação do Direito Constitucional e do Direito Civil.

Uma vez superados os referidos óbices conceituais à abordagem do caso aqui comentado, é relevante aprofundar a análise sobre a aplicação direta dos direitos fundamentais nas relações entre particulares, já à luz do caso concreto.

Os direitos fundamentais encontram-se disciplinados no ordenamento jurídico brasileiro sobretudo no Título II da Constituiçāo Federal. É certo que alguns dos direitos fundamentais destinam-se especificamente à atividade do Estado, como aquele incluído no art. $5^{\circ}$ da Constituição, por meio da Emenda Constitucional $n^{\circ} 45 / 2004$, que determina que a todos, no âmbito judicial e administrativo, são assegurados a razoável duração do processo e os meios que garantem a celeridade da sua tramitação.

Pela interpretação literal desse dispositivo constitucional, não é admissível discutir-se a aplicação direta desse direito fundamental entre particulares, já que um dos envolvidos será, necessariamente, o Estado, único ente capaz de prestar tutela jurisdicional.

De fato, é lícito afirmar-se que "o Estado é o 'principal destinatário' das normas de direito fundamental". ${ }^{21}$ Dessa forma, a Constituição funciona como limitador ao poder de agir do Estado, além de representar garantia significativa dos particulares contra arbitrariedades do poder público que venham a violar os direitos fundamentais. Assim, resta inquestionável que o Estado deve observar os direitos e garantias fundamentais.

Já quanto à aplicação diretamente às relações entre particulares dos direitos fundamentais, cabe ressaltar que não é em todos os países que tal teoria é aceita. Nos Estados Unidos, por exemplo, vigora a teoria da State Action, sobre a qual esclarece Daniel Sarmento:

"Lá, firmou-se o entendimento de que as normas constitucionais vinculam apenas o Estado, ressalvada apenas a $13^{\underline{a}}$ emenda, que proibiu a escravidão. A discussão está em saber em que casos a conduta de um particular pode ser de alguma forma imputada ao Estado, pois só através desta imputação é possível obrigar este particular a respeitar os direitos fundamentais consagrados pela Constituição."22

\footnotetext{
20 Ver, por todos, Michele Giorgianni. O direito privado e as suas atuais fronteiras. Revista dos Tribunais, São Paulo: Revista dos Tribunais, v. 747, p. 38

21 Jane Reis Gonçalves Pereira. Apontamentos sobre a aplicação das normas de direito fundamental nas relaçōes jurídicas entre particulares, cit., p. 137.

22 Daniel Sarmento. A vinculaçāo dos particulares aos direitos fundamentais no direito comparado e no Brasil, in Luis Roberto Barroso (Org.). A nova interpretaçãa constitucional: ponderą̧ão, direitos fundamentais e relações privadas. Rio de Janeiro: Renovar, 2003. p. 196.
} 
À parte dessa teoria adotada nos Estados Unidos, diversas são as teorias que pretendem explicar a eficácia dos direitos fundamentais nas relações entre particulares, ${ }^{23}$ tendo as primeiras surgido na Alemanha, nos anos 50 . Apenas a título de ilustração, podem-se reunir as principais teorias sobre o tema nos seguintes grupos:

a) teoria da eficácia imediata dos direitos fundamentais nas relaçōes privadas: esta teoria "postula a incidência erga omnes dos direitos fundamentais, que assumem a condição de direitos subjetivos em face de pessoas privadas que assumam posiçōes de poder. Nas situaçōes que envolvem iguais, embora não se aplique a finalidade protetora dos direitos fundamentais, estes também incidem diretamente, sendo empregados como parâmetros de aferição da validade de negócios privados"; 24

b) teoria da eficácia mediata ou indireta dos direitos fundamentais nas relações privadas: diversamente do que propõe a teoria anterior, neste caso, prega-se que os direitos fundamentais devem ser considerados pelo Estado quando da elaboração das leis ou na interpretação do direito privado. Dessa forma, seria sempre necessário que um órgão estatal (Legislativo ou Judiciário) atuasse como mediador para a aplicação dos direitos fundamentais em âmbito privado;

c) teoria dos deveres de proteção: por esta teoria, o Estado não só teria o dever de respeitar os direitos fundamentais dos cidadãos como também estaria obrigado a fazer com que os outros cidadãos também os respeitem.

De acordo com ordenamento jurídico pátrio, entende-se que os particulares devem necessariamente estar vinculados à aplicação dos direitos fundamentais em suas relações privadas. Do contrário, vários seriam os problemas práticos, conforme salientado por Jane Reis Pereira a respeito da questão: ${ }^{25}$

"É certo que, como já se enfatizou, uma abordagem puramente lógica do problema conduziria, facilmente, à conclusão de que os direitos fundamentais são também aplicáveis às relações privadas. Afinal, como observou Jean Rivero em passagem sempre lembrada, seria contraditório

\footnotetext{
3 Tais teorias são denominadas de "eficácia horizontal", ou seja, referem-se à possibilidade de aplicação dos direitos fundamentais entre particulares que estariam, hipoteticamente, em condiçōes de igualdade jurídica. Para discussão a respeito da matéria, ainda que com variantes acerca do tema, ver também Juan María Bilbao Ubillos. ¿En qué medida vinculan a los particulares los derechos fundamentales?, in Ingo Wolfgang Sarlet (Org.). Constituição, direitos fundamentais e direito privado. Porto Alegre: Livraria do Advogado Editora, 2003. p. 299 ss.

24 Jane Reis Gonçalves Pereira. Apontamentos sobre a aplicaçāo das normas de direito fundamental nas relaçōes jurídicas entre particulares. Cit., p. 160.

25 Jane Reis Gonçalves Pereira. Apontamentos sobre a aplicaçāo das normas de direito fundamental nas relaçōes jurídicas entre particulares. Cit., p. 138.
} 
defender a existência de 'duas éticas diferentes', para reger as relações públicas e as privadas, como se pudessem conviver em uma mesma sociedade 'duas concepçōes opostas ao homem'."

A autora cita, ainda, diversas situações fáticas envolvendo potenciais lesões a direitos fundamentais na esfera privada, cuja análise é, no mínimo, instigante. Embora a lista não seja exaustiva, vale citar, dentre as inúmeras hipóteses apontadas pela autora, as seguintes: (i) se ou até que ponto as liberdades (religiosas, de residência, de associação, por exemplo) ou bens pessoais (integridade física e moral, intimidade, imagem) podem ser limitadas por contrato, com o acordo ou o consentimento do titular; (ii) se uma empresa pode celebrar contratos de trabalho com cláusulas pelas quais os trabalhadores renunciem a exercer atividades partidárias ou a sidicalizar-se etc. ${ }^{26}$ Pode-se, com referência ao caso aqui analisado, inserir entāo outra hipótese: até que ponto a vida privada e a intimidade de um indivíduo podem ser limitadas em favor da liberdade de informar e da liberdade de expressão? Ou, ao revés, até que ponto pode o acesso à informação ser cerceado para satisfazer demandas individuais?

Assim, parece evidente que não é apenas o Estado que pode pôr em risco direitos fundamentais dos particulares, de modo que, diante da ameaça potencial por parte dos próprios particulares, desnecessária a argüição sobre a possibilidade de aplicação dos direitos fundamentais às relações entre particulares.

Ao elencar alguns aspectos relevantes na justificação da incidência de direitos fundamentais nas relações privadas, Jane Reis argumenta que:

"Um outro aspecto a ser considerado é a proximidade da relação jurídica entre particulares da esfera pública. Embora os lindes entre espaço público e espaço privado apresentem-se cada vez mais tênues, tal aspecto deve ser tido em consideração ao determinar-se a vinculação dos particulares aos direitos fundamentais. Quanto mais próxima à esfera privada revelar-se uma relação jurídica, menor a possibilidade de um direito fundamental vir a prevalecer sobre a autonomia privada. Traduzindo essa idéia em exemplos, não há como cogitar de que os pais sejam obrigados a dar a seus filhos presentes de Natal semelhantes - ou que lhes devam oferecer mesadas idênticas, ou mesmo castigar-lhes de forma equivalente - em obediência ao comando da igualdade. Mas uma resposta diferente deveria ser dada à seguinte questão hipotética: poderia uma escola privada estabelecer que os meninos tenham prioridade sobre as meninas no preenchimento das vagas nos cursos de verão? Nesse último caso, é intuitivo que o preceito isonômico poderia servir de razão contraposta à liberdade da escola de gerenciar seus cursos. E isso não decorre apenas de tratar-se de uma relação de poder privado. É a inserção social da Escola - e conseqüentemente - sua 
aproximação da esfera pública, que determina a possibilidade de exigir desta respeito ao princípio da não-discriminação" (grifo nosso). ${ }^{27}$

A partir dos exemplos citados pela autora, pode-se suscitar um relevante paralelo. Afirma a autora que " $[\mathrm{u}] \mathrm{m}$ outro aspecto a ser considerado é a proximidade da relação jurídica entre particulares da esfera pública”. E, mais adiante, que "[q]uanto mais próxima à esfera privada revelar-se uma relação jurídica, menor a possibilidade de um direito fundamental vir a prevalecer sobre a autonomia privada".

É evidente que a Internet exerce atualmente, também, um papel social. Sua importância social, seu impacto, a possibilidade de funcionar como ferramenta na formação do indivíduo talvez só encontre paralelo no mundo contemporâneo com a televisão. Aproxima-se, portanto, da esfera pública no sentido de que, assim como a escola (se bem que assistemática e apenas potencialmente) ou a televisão (ainda que em abrangência hoje significativamente menor), atua na sociedade instruindo, informando e criando conceitos, modismos e, evidentemente, formando opinião.

Valendo-nos das premissas lançadas no início deste item 3.2, pode-se afirmar que, no caso em análise, há um conflito entre direitos fundamentais: o direito à intimidade dos autores e o direito de liberdade de expressão das empresas rés. Tanto é assim que na declaração de voto divergente do Agravo de Instrumento ${ }^{0}$ 472.738-4, referente ao pedido de antecipação de sentença por violação do direito à imagem, à privacidade, à intimidade e à honra, o desembargador Maia da Cunha assim se pronunciou:

"Não antevejo o risco de lesão grave e de difícil reparação [quanto ao eventual dano ao direito à imagem, à privacidade, à intimidade e à honra dos autores]. Na esteira do mesmo raciocínio desenvolvido, sobre ser previsivel a utilização de fotos ou filmes pela mídia diante da aberta exposição da imagem promovida pelos próprios agravantes, quando protagonizaram as cenas numa praia pública, parece certo que eventual violação a direito dos autores poderá ser reparado plenamente pela via pecuniária.

A verificação do dano de difícil reparação, ou perigo da demora, contém, no caso, uma agravante: o risco de se ferir a liberdade de informação também garantida pela Constituição Federal.

\section{$[\ldots]$}

Também a liberdade da imprensa e o direito à informação pelos veículos de comunicação social não podem mais ser pensados sem a força da presença da internet, dada à rapidez com que os fatos são divulgados e 
vistos pelos que freqüentam a rede mundial de computadores. Impõe-se cuidado ainda maior, no caso, para não ferir inutilmente a liberdade de imprensa e o direito de informar, o que se afirma porque o que se proibirá já é do domínio público."

Não obstante a ponderação acima, fato é que em razão de decisão posterior do mesmo Tribunal, foi determinado o bloqueio total do vídeo veiculado pela Internet, o que resultou na impossibilidade de acesso ao site Youtube por pelo menos cinco milhões de usuários no Brasil.

Sabe-se que quando dois princípios ${ }^{28}$ fundamentais (direito à honra e liberdade de expressão, por exemplo) entram em conflito, há que ponderá-los para saber qual dos princípios, no caso concreto, deverá prevalecer. A decisão, qualquer que seja, deverá, entretanto, estar revestida de proporcionalidade. Nesse ponto, indaga-se: diante da contraposição dos princípios fundamentais, conforme visto acima, houve proporcionalidade ${ }^{29}$ na decisāo que proibiu o acesso ao site YouTube? Em outras palavras: é uma decisão proporcional impedir o acesso de um website por vários milhões de usuários a fim de impedir que um único vídeo seja acessado?

Neste momento, a análise da proporcionalidade da decisão mostra-se pertinente. Conforme leciona Virgílio Afonso da Silva:

"Se se admite que a grande maioria dos direitos fundamentais são princípios, [...], admite-se que eles são mandamentos de otimização, isto é, normas que obrigam que algo seja realizado na maior medida possível, de acordo com as possibilidades fáticas e jurídicas. $\mathrm{E}$ a análise da proporcionalidade é justamente a maneira de se aplicar esse dever de otimização ao caso

\footnotetext{
28 "Alexy divide as normas jurídicas em duas categorias, as regras e os princípios. Essa divisão não se baseia em critérios como generalidades e especialidades da norma, mas em sua estrutura e forma de aplicação. Regras expressam deveres definitivos e são aplicadas por meio de subsunçāo. Princípios expressam deveres prima facie, cujo conteúdo definitivo somente é fixado após sopesamento com princípios colidentes. Princípios sāo, portanto, 'normas que obrigam que algo seja realizado na maior medida possivel, de acordo com as possibilidades fáticas e jurídicas', sāo, por conseguinte, mandamentos de otimização" (grifos do autor). Luís Virgílio Afonso da Silva. O proporcional e o razoável, in Revista dos Tribunais, v. 798, p. 23 ss.

29 Conforme muito bem orienta Luís Virgílio Afonso da Silva, os conceitos de razoabilidade e de proporcionalidade podem ser tidos, laicamente, como intuitivos. Aqui, entretanto, tratamos da proporcionalidade em sua concepção jurídica. E mesmo nesse sentido cabe uma observação. A doutrina parece tratar a análise da proporcionalidade sobretudo no que diz respeito a atos emanados dos poderes Legislativo e Judiciário. No entanto, aqui nos valemos do princípio de maneira ampla de modo a abranger, também nele, a análise de atos judiciais. Valemo-nos da Iição de Luís Roberto Barroso, ao afirmar que "o princípio da razoabilidade [que o autor entende ter, de acordo com a doutrina e a jurisprudência da Europa e do Brasil, significado intercambiável com o princípio da proporcionalidade, motivo pelo qual sofre críticas de Luís Virgílio Afonso da Silva] é um parâmetro de valoração dos atos do Poder Público para aferir se eles estão informados pelo valor superior inerente a todo ordenamento jurídico: a justiça. [...] É razoável o que seja conforme a razão, supondo equilíbrio, moderaçāo e harmonia; o que não seja arbitrário ou caprichoso; o que corresponda ao senso comum, aos valores vigentes em dado momento ou lugar" (in Interpretação e aplicação da constituição: fundamentos de uma dogmática constitucional transformadora. 5. ed. Rio de Janeiro: Saraiva, 2003. p. 224).
} 
concreto. É por isso que se diz que a regra da proporcionalidade e o dever de otimização guardam uma relação de mútua implicação". ${ }^{30}$

A análise da proporcionalidade de determinado ato é realizada a partir de três sub-regras ou elementos. O primeiro é a adequação; o segundo, a necessidade; e, finalmente, a proporcionalidade em sentido estrito. ${ }^{31}$

A adequação consiste em se verificar se o ato é capaz de alcançar o resultado que se pretende com a medida. Caso venhamos a fazer análise sistemática da decisão que resultou na interdição do website YouTube, verificaremos que a medida era aparentemente adequada - se assim pudermos nos expressar - embora, na prática, insuficiente.

Naturalmente, se o que se pretendia era impedir que o vídeo repudiado fosse acessivel pelo website YouTube, entāo a medida era adequada. Afinal, uma vez que o website se tornasse inacessível, conseqüentemente o vídeo também o seria. Mas nesse passo entra o primeiro grande complicador da história: o vídeo nāo era passível de ser encontrado apenas no website YouTube. Uma vez inserido na rede mundial de computadores, muito difícil garantir que a proibição de acesso de um conteúdo por meio de determinado website resultará no banimento de referido conteúdo de toda a rede. Mas trataremos do assunto no próximo item.

Supondo que se possa considerar adequada a medida, deve-se analisar sua necessidade. Segundo Luís Virgílio, "um ato estatal que limita um direito fundamental é somente necessário caso a realização do objetivo perseguido não possa ser promovida, com a mesma intensidade, por meio de outro ato que limite, em menor medida, o direito fundamental atingido". ${ }^{32}$

Ora, como se verá adiante, a filtragem sempre extrapola os limites do desejado, ou seja, sempre representará uma limitação além do necessário. No caso concreto, o que se viu foi um grupo relevantíssimo de usuários da Internet - mais de cinco milhões - impedidos de acessar milhares de vídeos legitimamente inseridos na rede a fim de se evitar que assistissem a um único vídeo.

Embora não ultrapasse o segundo passo da análise da proporcionalidade, o que isentaria de continuar o caminho até seu terceiro e último elemento, deve-se proceder a tal verificaçāo apenas para que se compreenda a gravidade da decisāo.

Diz-se que o terceiro e último elemento da aferição da proporcionalidade é a proporcionalidade em sentido estrito. Consiste em "um sopesamento entre a intensidade da restrição ao direito fundamental atingido e a importância da

Luís Virgílio Afonso da Silva. O proporcional e o razoável. Revista dos Tribunais, v. 798, p. 43-44.

Para análise detalhada da matéria, ver Luís Virgílio Afonso da Silva. O proporcional e o razoável. Revista dos Tribunais n" 798, p. 23 ss, e Jane Reis Gonçalves Pereira. Direitos fundamentais e interpretação constitucional: uma contribuição ao estudo dos limites e restriçōes aos direitos fundamentais na perspectiva da teoria dos principios. Tese de Doutorado defendida na Universidade do Estado do Rio de Janeiro - UERJ, orientada pelo professor Luís Roberto Barroso. 2004.

32 Luís Virgílio Afonso da Silva. O proporcional e o razoável, cit., p. 38. 
realização do direito fundamental que com ele colide e que fundamenta a adoção da medida restritiva". ${ }^{33} \mathrm{Ou}$, como afirma Jane Reis, "é preciso determinar se $o$ atendimento à finalidade buscada pela medida restritiva compensa os prejuízos que desta advenham para os direitos fundamentais". ${ }^{34}$

Também aqui, mais até do que no item anterior, verifica-se a gravidade da decisão do TJSP. Mesmo que se admitisse que o fim fosse plenamente atingido com a supressão do acesso ao site YouTube e que esta era a única maneira de se atingir o fim desejado - o de se impedir acesso ao vídeo -, tal análise não se sustentaria sob o prisma da proporcionalidade em sentido estrito. Afinal, os danos causados pela vedação de acesso são tão grandes e desproporcionais ao prejuízo que se pretende evitar que não poderiam ser considerados admissíveis do ponto de vista da proporcionalidade. Para essa análise, entretanto, é indispensável a menção a alguns dos aspectos tecnológicos que envolvem o caso.

\section{Questionamentos sobre a tecnologia da filtragem de conteúdo}

Existem algumas questões relacionadas ao desenvolvimento tecnológico relevantes para o deslinde do caso aqui comentado, e cuja compreensão demonstra tanto a gravidade da decisão adotada pelo TJSP como a necessidade de se estabelecerem parâmetros para uma decisão judicial que envolva a veiculação de conteúdo na Internet.

De início, faz-se necessário tecer algumas críticas à escolha pela filtragem do conteúdo veiculado por um website. Diversas são as ações judiciais que têm buscado a retirada de conteúdo de um website quando a sua exibição desagrada, constrange, ou mesmo atinge algum direito da personalidade da eventual vítima. Associado ao pedido de retirada de um determinado conteúdo, é comum que também seja ordenado algum tipo de providência para garantir que o conteúdo impugnado não venha novamente a ser exibido. Reside nos websites cujo conteúdo é formado de modo colaborativo boa parte das dificuldades relacionadas à técnica de filtragem. Além de ser ineficaz no aspecto tecnológico, a inserção de mecanismo de filtragem de conteúdo apresenta uma série de questionamentos abaixo comentados.

Quem filtra o filtro? Quais são os critérios utilizados para a inserção de mecanismo de filtragem em determinado website? Essa é a primeira questão que pode ser levantada sobre a opção pelo bloqueio de conteúdo na Internet. A maior parte das decisōes judiciais que determinam a retirada de algum material de um website apenas determina que o réu assim o faça, cumprindo com uma obrigação de fazer.

\footnotetext{
33 Luís Virgílio Afonso da Silva. O proporcional e o razoável, cit., p. 40.

34 Jane Reis Gonçalves Pereira. Direitos fundamentais e interpretação constitucional: uma contribuição ao estudo dos limites e restrições aos direitos fundamentais na perspectiva da teoria dos princípios, cit., p. 307.
} 
Geralmente não se especifica quais serão os termos utilizados para o estabelecimento do filtro, quais expressōes serão proibidas etc.

A indefinição sobre o que filtrar faz com que, na maior parte das vezes, a técnica adotada termine por ser decidida justamente pela ré, que opera o website e sofre os efeitos da decisão judicial. Embora louváveis sejam os esforços no sentido de se reprimir a veiculação de conteúdo lesivo através do website, a não-definição de critérios para essa operação pode ser um primeiro obstáculo ao atendimento da ordem judicial.

A indefinição sobre os critérios de filtragem, todavia, é apenas um de, pelo menos, três efeitos de sua adoção que terminam por evidenciar o equívoco na sua escolha como meio a ser adotado para a proteção dos direitos da personalidade na rede mundial de computadores. Os três efeitos, cada qual com as suas peculiaridades, levam à conclusão de que a filtragem de conteúdo deve ser, na maior parte das situações, a última opção para a tutela dos interesses eventualmente lesionados.

A filtragem é ineficaz. Antes mesmo de adentrar questões mais complexas como os limites da filtragem e o princípio da neutralidade da rede, é importante destacar que a opção por esse mecanismo de restrição de certo conteúdo jamais será perfeito. Em outras palavras, a filtragem de conteúdo jamais garantirá que um vídeo, texto ou áudio, por exemplo, deixem de ser possivelmente acessados por quem tiver interesse na sua exibição.

Isso ocorre porque existem mecanismos tecnológicos bastante simples e disponíveis na Internet que tornam possível burlar os filtros utilizados. Se o conteúdo bloqueado ou filtrado for um vídeo, por exemplo, e o filtro foi colocado no nome dado ao vídeo, então para que o filtro seja burlado basta mudar apenas o nome do arquivo de vídeo. Com uma simples alteração como essa o filtro não irá reconhecer o arquivo como sendo aquele previamente restringido.

Caso o filtro tenha sido feito pela URL, ou seja, pelo endereço do vídeo na Internet, basta a criação de outra URL para que o mesmo vídeo possa ser exibido, uma vez que a referência para bloqueio era o seu endereço anterior.

Por fim, caso a filtragem ocorra no website inteiro, bloqueando seu conteúdo por completo, basta ao usuário acessar o mesmo website por um servidor proxy, ${ }^{35}$ iludindo o mecanismo de filtragem. Vale ainda ressaltar que, pela própria natureza da Internet, a exclusão de um vídeo de um ou vários websites não garante que outros tantos websites não venham a hospedá-lo no futuro. Sendo assim, de pouco adiantaria a obtenção de medida judicial contra certas empresas que exploram famosos e acessados websites. Essa medida pode até mesmo reduzir o impacto da exibição do material, mas não o banirá por completo da Internet.

A ausência de um centro de controle da rede mundial sempre foi uma das características mais marcantes da Internet e uma das suas especificidades técni-

Cf. Brasil Telecom censura a Internet no Brasil bloqueando acesso ao YouTube. Disponível em: $<$ http://www.softwarelivre.org/news/8219>. Acesso em: 6 jan. 2007. 
cas que maior repercussão causa no próprio conteúdo que por ela circula. A rede descentralizada até então garantiu um pluralismo cultural e uma liberdade de expressão poucas vezes experimentada nos meios de comunicação.

Como ressaltado por Tim Bernes-Lee, tido como um dos "pais" da Internet, ao detalhar as perspectivas que poderiam ser adotadas para a construção de sua arquitetura:

"Entre inspirações por desejos de natureza mercadológica e ideais humanísticos, percebemos que a adoção da perspectiva do controle era uma opção errada. Eu deixei claro que havia desenhado a rede para que não houvesse um centro no qual as pessoas deveriam registrar um novo servidor ou obter aprovação para inserção de novo conteúdo. Qualquer um poderia construir um novo servidor ou inserir um novo conteúdo. Filosoficamente falando, se a Internet deveria ser um bem universal, ela deveria crescer de forma ilimitada. Tecnologicamente falando, se houvesse um ponto de controle, ele rapidamente se tornaria um gargalo para o crescimento da Internet e ela jamais ganharia a escala desejada. A sua falta de controle era o que importava." 36

Como preservar esse ambiente, essa verdadeira ecologia da liberdade, sem permitir lesões graves a direitos legítimos de terceiros é o problema que a opção pela filtragem coloca.

Pode ser mencionado ainda que outra forma de tornar ineficaz o bloqueio é disponibilizar o conteúdo em ferramentas de compartilhamento, tais como os softwares que operam em redes peer-to-peer (P2P), como eMule, BitTorrent, LimeWire, SoulSeek etc. Como esses softwares permitem a troca de arquivos on line entre os mais diversos usuários, o conteúdo impugnado pode até ser banido da rede $\mathrm{P} 2 \mathrm{P}$ através de filtros, mas os usuários que já obtiveram o arquivo não serão afetados por essa medida.

\section{A filtragem extrapola os limites específicos para os quais foi implemen-} tada. Uma vez determinada a filtragem de certo website, e definidos os termos que serão objeto do bloqueio, é comum perceber-se que esse mecanismo termina por impedir o acesso a conteúdos outros que não aqueles cuja exibição se procurava proibir. ${ }^{37}$

A proliferação de decisões judiciais determinando a filtragem pode ocasionar sérios danos à neutralidade da rede, conforme se verá adiante. Todavia, antes mes-

\footnotetext{
36 Tim Bernes-Lee. Weaving the Web: the original design and ultimate destiny of the World Wide Web by its inventor. New York: HarperCollins, 1999, p. 99.

3.- Tornou-se célebre na Internet o bloqueio de websites que relatavam a exploração espacial do planeta Marte por um carro-robô da Nasa, pois a maior parte dos filtros inseridos em computadores domésticos para a navegaçāo de crianças impedia o acesso a sites que contivessem a palavra sexo. Em inglês, juntando-se as palavras Mars (Marte) e Exploration (exploraçāo), obtinha-se a palavra sex, bloqueada pelos referidos filtros.
} 
mo de qualquer reflexão crítica sobre a neutralidade da Internet e o livre fluxo de conteúdo, é importante perceber a armadilha gerada por sucessivos bloqueios de conteúdo em um mesmo website e quais pessoas, em última instância, seriam as vítimas desse mecanismo.

Imagine-se que uma pessoa ingresse com ação judicial para retirar um determinado vídeo que ofende a sua honra e imagem de um certo website de conteúdo colaborativo, como o YouTube, por exemplo. O mecanismo adotado para garantir a pretensa efetividade da decisão judicial é a determinação do estabelecimento de filtros no website para impedir que aquele vídeo volte a ser exibido. Esse vídeo, por sua vez, precisa ser identificado pelo mecanismo de filtragem e isso será feito através da inserção de palavras-chave que o caracterizam, mais notadamente o nome da autora da açāo judicial e outras circunstâncias específicas.

A adoção de medida como essa, conforme já visto, não é suficiente para banir a exibição do vídeo, pois a tecnologia oferece uma dúzia de alternativas para superar tal bloqueio. Mas o que interessa para a presente discussão são os efeitos dessa medida. Quantos outros materiais, legitimamente inseridos no website, não serão restringidos pelos termos ou expressões analisados pelo filtro?

Adicionalmente, uma vez tendo o seu conteúdo afetado pela inserção de filtro cujo escopo era o bloqueio de outros materiais, de que medida pode se valer o usuário afetado para voltar a ter o seu vídeo, o seu texto, ou a sua foto, por exemplo, novamente exibidos no website? Certamente identificar as razões pelas quais o seu material foi abrangido pelo filtro é o primeiro passo. Caso alguma expressão, termo ou referência constante de seu material tenho sido bloqueada, bastaria ao usuário alterá-la.

Infelizmente essa alternativa nem sempre é de fácil adoção e, em casos extremos, optando o usuário injustamente afetado por mover ação judicial pelos eventuais danos sofridos, pergunta-se: contra quem seria movida tal ação? Contra a pessoa que, sentindo-se inicialmente violada em seus direitos da personalidade pela exibição de um material no mesmo website, ingressou com a ação judicial que resultou na colocação do filtro?

Parece claro que, em situações como essa, a ação judicial movida pelo usuário prejudicado teria como alvo justamente a empresa que explora o website de conteúdo colaborativo (o provedor) pela colocação do filtro que gerou tantos problemas. Mas a colocação do filtro não foi determinada judicialmente justamente para sanar problemas de outra ordem, como a infração à honra e à imagem da autora da primeira ação?

Esse é o movimento da propagação dos danos gerado pela filtragem. Do cenário inicial, no qual havia apenas uma vítima, ofendida pelo conteúdo injurioso hospedado no website, evolui-se para um cenário no qual existem, pelo menos, mais outras duas vítimas: o usuário que teve o seu conteúdo indevidamente bloqueado e o próprio provedor, que não apenas é obrigado a restringir os materiais constantes de suas páginas, como ainda tornou-se réu em mais um processo judicial. 
A posição do provedor, que sofre nas duas pontas desse triângulo de relações, será explorada adiante, quando se detalhar alguns parâmetros para a responsabilização por danos causados na Internet. O estágio atual da legislação e jurisprudência pátrias coloca o provedor em situação bastante desconfortável pois, independentemente da conduta adotada, continuará pairando sobre o mesmo a expectativa de que exista alguém, em algum lugar, que, por algum motivo, sentiuse ofendido, ou com o material por ele exibido, ou justamente com o material que deixou de exibir.

Reforçando o entendimento sobre os malefícios da filtragem, pode-se mencionar a lição de Sofia de Vasconcelos Casimiro, segundo a qual as referidas técnicas "apresentam, contudo, alguns problemas que parecem incontornáveis e que se relacionam com o facto de, por um lado, bloquearem mais conteúdo do que os pretendidos, podendo assim redundar numa dissimulada censura, e de, por outro lado, só acturarem nas aplicaçōes do sistema World Wide Web e não em todas as fontes de conteúdo indesejável, como seja, por exemplo, nos fóruns de discussão. Verifica-se ainda que estes programas são concebidos para os utilizadores individuais e dependem de considerações culturais que, podendo ser mais homogêneas dentro de determinada comunidade, dificilmente são transponíveis e coadunáveis a um país inteiro ou, muito menos, ao mundo inteiro". ${ }^{38}$

Vale ressaltar ainda que quando o objeto do bloqueio pelo filtro é o nome de determinada pessoa física, existe o risco de se vetar a exibição de conteúdos relacionados com homônimos. Situações como essa demonstram que a opção pela filtragem não é adequada ao ambiente de troca de informações criado pelo desenvolvimento da rede mundial de computadores.

A filtragem afeta a neutralidade da rede. Para além da determinação da retirada do vídeo impugnado do website YouTube, a decisão proferida pelo TJSP atingiu milhões de usuários da Internet brasileira ao determinar que o acesso integral ao referido website fosse bloqueado. Por mais que nova decisão, publicada dias depois, tenha esclarecido que não havia sido essa a determinação judicial, duas empresas que operam os backbones da rede brasileira atenderam ao que parecia, pelo que constava de seus próprios termos, ser o objeto da ordem judicial.

Com uma medida de tais proporções, o Brasil ingressou de forma inusitada no rol de países que bloqueiam a priori o conteúdo da rede mundial de computadores disponível para usuários que acessam através de seus territórios. Esse tipo de medida fere frontalmente um dos fundamentos principais do sucesso e expansão da Internet como hoje conhecida: a sua neutralidade, ou, em outras palavras, a não-interferência prévia e discricionária no conteúdo que pode ou não ser exibido.

Pode-se traçar um paralelo com as comunicações ocorridas através das linhas telefônicas. Não existe, previamente, um modelo de comunicação a ser seguido,

38 Sofia de Vasconcelos Casimiro. A responsabilidade civil pelo conteúdo da informação transmitida pela Internet. Coimbra: Almedina, 2000, p. 39. 
fazendo com que a verbalização de certas palavras ou a comunicação de certo conteúdo seja a priori proibido. Caso alguém seja ofendido pelo conteúdo da comunicação, resta sempre o recurso a medidas judiciais, que serão movidas apenas se e quando for identificada uma lesão a certos direitos legitimamente protegidos.

Apenas em casos extremos, cujo consenso na sociedade como um todo seja notório, legitimando-se histórica e antropologicamente, como parece ser o caso da pornografia infantil, poderia-se aventar um controle prévio sobre o conteúdo das comunicações na Internet.

A situação da pornografia infantil é distinta daquela enfrentada por países como China, Arábia Saudita e, mais recentemente, Tailândia, nos quais existe uma censura prévia sobre o conteúdo passível de acesso na Internet. O que parece afastar os dois casos é justamente conjunto de interesses que move a seleção dos materiais proibidos.

O debate sobre a neutralidade da rede mundial de computadores atualmente ganha espaço e a decisão do TJSP contribui para fomentar a sua discussão no Brasil, expondo a dificuldade de se compatibilizar uma rede de comunicações livre como a Internet e os mais diversos interesses das pessoas que dela se valem para trabalhar, estudar e se entreter. ${ }^{39}$

Há diversos estudos feitos sobre o assunto, sendo válido mencionar o estudo $^{40}$ feito pelo Berkman Center for Internet \& Society, da Universidade Harvard.

No referido estudo, há interessantes dados sobre bloqueios na Arábia Saudita e na China. Na Arábia Saudita, por exemplo, milhares de websites foram bloqueados, incluindo sites com informações sobre saúde, educação, mulher, humor, entretenimento etc. Websites como o da revista sobre música Rolling Stone, ${ }^{4 !}$ o de busca de filmes da Fox, FoxSearchLight, ${ }^{42}$ bem como sobre o museu em Amsterdã da sobrevivente do Holocausto nazista, Anne Frank House, ${ }^{+3}$ foram inteiramente bloqueados.

Qual será, enfim, o critério para bloquear um determinado website? Será mesmo que o bloqueio prévio é a melhor solução? Se parece haver consenso sobre os malefícios do bloqueio prévio por influir na neutralidade da rede, a discussāo realizada até aqui mostra que o bloqueio feito a posteriori, determinado judicialmente, também não está isento de críticas.

\footnotetext{
39 Curioso notarmos que no mesmo dia 9 de janeiro de 2007, data em que o TJSP esclareceu que nāo exigiu o bloqueio do YouTube inteiro, senadores norte-americanos trouxeram de volta à pauta a discussão sobre a neutralidade da web, por meio do Internet Freedom Preservation Act. Cf. Gross, Grant: Senadores dos EUA recolocam projeto sobre neutralidade na web em pauta. Disponivel em: <http:// idgnow.uol.com.br/internet/2007/01/10/idgnoticia.2007-01-10.8286737443/IDGNoticia_view $>$. Acesso em: 10 jan. 2007 .

tr Cf. Zittrain, Jonahan; Edelman, Benjamin: Documentation of Internet filtering worldwide. Disponivel em: < http://cyber.law.harvard.edu/filtering/>. Acesso em: 4 fev. 2007.

$\because$ Cf. <http://www.rollingstone.com/>. Acesso em: 4 fev. 2007.

i2 Cf. <http://www.foxsearchlight.com/index.php>. Acesso em: 4 fev. 2007.

t3 Cf. <http://www.channels.nl/amsterdam/annefran.html >. Acesso em: 4 fev. 2007.
} 
Se a filtragem não parece ser a melhor solução, é importante refletir sobre quais deveriam ser os parâmetros adotados por um juiz perante um caso sobre a retirada de conteúdo pretensamente ofensivo da Internet. ${ }^{44}$

\section{Parâmetros para uma nova legislação sobre responsabilização civil na Internet}

Nem todos os novos conflitos surgidos por conta da expansão da Internet no Brasil demandam a edição de uma legislação específica. Em diversas oportunidades a aplicação em maior grau do Código de Defesa do Consumidor e do Código Penal e, em menor grau, do Código Civil obteve uma solução satisfatória para o deslinde de litígios derivados do uso das novas tecnologias de comunicação digital.

No caso das diversas açōes indenizatórias que vêm sendo propostas no país, a diversidade de decisões judiciais proferidas, acentuando o ônus ressarcitório ora nos provedores de serviços, ora nos usuários que publicam o conteúdo impugnado na Internet, demonstra a necessidade de se erigirem alguns parâmetros que possam servir de guia para o juiz ao analisar um caso envolvendo a retirada de materiais da rede mundial de computadores e o conseqüente pleito indenizatório.

Não se trata, é bom esclarecer, de imperiosa necessidade por uma legislação que afirme peremptoriamente quem responde em tal ou qual situação. Uma legislação que apresente soluçōes fáceis certamente não compreende a complexidade do assunto em discussão. Mas a indicação de parâmetros parece atender às demandas por alguma previsão sobre o resultado de ações como essas.

Enquanto não se edita norma com o referido teor, não apenas a doutrina vacila no encontro de soluções para remediar problemas de natureza prática que surgem em velocidade superior aos dilemas que a tradicional pesquisa jurídica não está acostumada, mas a própria jurisprudência também não parece evidenciar certo desconforto com a pluralidade de decisões das mais diversas, cada qual seguindo um rumo distinto na abordagem do tema. Poderia-se falar mesmo que esse cenário se caracteriza "por uma hesitação doutrinal e jurisprudencial no enquadramento a dar a questão, na falta de legislação específica sobre o tema". ${ }^{45}$

$\mathrm{Na}$ ausência de tal legislação, praticamente todas os protagonistas de uma açāo indenizatória sofrem os efeitos dessa ausência de balisamentos. $\mathrm{O}$ usuário que colocou o conteúdo impugnado em determinado website sofre o ônus da incerteza sobre o impacto que o seu material poderá ter na percepção de terceiros. Se qualquer pessoa pode, potencialmente, mover uma ação indenizatória contra o

* Cf. Leia a íntegra da medida que manda desbloquear o YouTube no Brasil. Disponível em: <http:// idgnow.uol.com.br/internet/2007/01/09/idgnoticia.2007-01-09.7954769479/IDGNoticia_view >. Acesso em: 4 fev. 2007.

45 Sofia de Vasconcelos Casimiro. A responsabilidade civil pelo conteúdo da informaçāo transmitida pela Internet. Coimbra: Almedina, 2000, p. 42. 
mesmo, certamente haverá um certo receio na exibição de conteúdos que podem ser considerados polêmicos, embora não necessariamente ilícitos.

Adicionalmente, o provedor de serviços que hospeda o conteúdo inserido por seu usuário também arcará com boa parte do ônus da mencionada incerteza. Todavia, a situação do provedor ganha alguns contornos que precisam ser esclarecidos. A maior parte das açōes indenizatórias propostas no país visam, ao menos inicialmente, ao provedor de serviços. É ele que, no ambiente da Internet, hospeda e exibe o conteúdo, sendo certo que opção por ingressar contra eventual ação indenizatória contra o provedor também é pautada por questões econômicas (pois, na maior parte das vezes, o provedor possui maiores condiçōes financeiras de arcar com a indenização do que o seu usuário). ${ }^{46}$

Dessa forma, o provedor de serviços que opere website de conteúdo colaborativo convive com a constante ameaça de novas açōes judiciais. Como medida para evitar novas ações, pode-se presumir que uma prática de monitoramento constante no conteúdo inserido no website por seus usuários seja uma das atividades desempenhadas com afinco pelo provedor.

Essa percepção, todavia, esbarra em dois óbices relevantes. Inicialmente, o monitoramento perfeito de um website de conteúdo colaborativo demanda a contratação de numerosa equipe para varrer, dependendo do tamanho do website, toda a extensão de materiais hospedados. A inserção de mecanismos de filtragem automatizados, como visto, apresenta uma série de imperfeições que apenas a observação humana pode suprir.

Contudo, a contratação de equipe numerosa e especializada para a leitura e a remoção prévia do conteúdo do website não é medida suficiente para aplacar o risco de eventuais ações judiciais. Isso se deve ao fato de que os critérios de avaliação de um conteúdo como lesivo à honra, privacidade e imagem de terceiros, por exemplo, são extremamente pessoais. Na ausência de um critério uniforme, certamente o provedor optará pela retirada em detrimento da manutenção de conteúdo polêmico. Essa decisão não apenas empobrece o universo de conteúdo relacionado ao seu website como, em escala, termina por impor uma espécie de censura prévia que discrimina o que pode e o que não pode ser exibido na rede mundial de computadores.

Ao destacar a inusitada situação em que se encontra o provedor, como intermediário entre o seu usuário e o público em geral, do qual poderá surgir uma eventual vítima, assim resume Ronaldo Lemos:

"O que chama a atenção quanto à responsabilidade do intermediário no Brasil, é que, diferentemente de outros países, não foi estabelecido nenhum critério legal para isençāo ou atribuição de responsabilidade

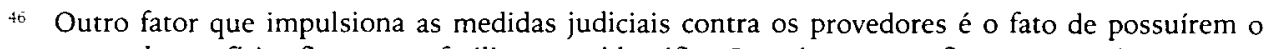
mesmo endereço físico fixo, o que facilita a sua identificação e citaçāo para fins processuais. 
ao intermediário, mediante o recebimento de notificação. Dessa forma, o provedor de acesso à Internet por temor e incerteza quanto ao resultado de uma eventual decisão judicial, fica propenso a efetivamente retirar o conteúdo, sem qualquer verificação de sua legitimidade, não tendo, ao contrário, nenhum incentivo para fazer de modo diferente. Note-se que não há qualquer regime de previsão de 'porto seguro' no país que especificamente isente o provedor de responsabilidade, caso ele cumpra determinados requisitos." ${ }^{47}$

Ainda sobre os ônus que recaem sobre a figura do provedor, vale mencionar que a sua situação é bastante peculiar pois, se por um lado ele teme o ingresso de novas açōes judiciais e por isso retira conteúdo de seu website, essa mesma medida pode dar ensejo à ação judicial, agora nāo mais de um terceiro ofendido, mas sim de seu próprio usuário que se sinta lesionado em seu direito de liberdade de expressão. ${ }^{48}$

Por fim, depois do usuário do website e seu provedor, a própria vítima do suposto dano é também uma protagonista dessa situação que carrega a sua cota de ônus. A vítima, ao ingressar com uma ação judicial para a retirada do conteúdo, possui grandes chances de ver o seu pleito frustrado pelo simples fato de que um conteúdo uma vez postado na Internet pode ser reproduzido geralmente sem maiores dificuldades em outros websites, operados por outras pessoas físicas ou jurídicas. Essa simples percepção denota como a arquitetura da Internet dificulta o atingimento da eficácia do provimento judicial, deixando igualmente frustrados o autor da demanda e o próprio julgador.

O que está em jogo em questões como essa é o futuro da inovação na Internet brasileira. A ausência de uma legislação específica com o delineamento de parâmetros para o julgamento de ações judiciais envolvendo a retirada de conteúdo da Internet e o seu conseqüente pleito indenizatório gera uma rede de inseguranças, receios e decisões antecipadas que em nada contribuem para a expansão de novas idéias sobre aplicativos e serviços; ao contrário, fazem de cada nova decisão judicial uma externalidade prejudicial e muitas vezes inusitada sobre o desenvolvimento das atividades dos provedores e um transtorno constante para os usuários que transformam os websites colaborativos em verdadeiros repositórios de textos, vídeos, fotos etc.

O prejuizo causado à inovação na Internet nacional passa necessariamente pela constatação da mencionada redução proposital de conteúdo dos provedores. Como lembra Ronaldo Lemos, "uma grande parte do conteúdo da rede, ainda

\footnotetext{
47 Ronaldo Lemos. Direito, tecnologia e cultura. Rio de Janeiro: Editora FGV, 2005, p. 125.

48 Esse tipo de receio acaba sendo resolvido pelo termo de uso do website que, ao especificar as condiçōes do serviço prestado, informa ao usuário que o provedor poderá retirar do ar certos conteúdos referidos.
} 
que legítimo, deixa de ter qualquer proteção jurídica, ficando sujeita à atividades de entidades de classe e advogados em nome de interesses específicos que, com ameaça aos intermediários, conseguem retirar, sem que haja maior escrutínio, conteúdo eventualmente legítimo da rede". ${ }^{49}$

Dessa forma percebe-se como a filtragem de conteúdo representa uma das questōes mais polêmicas sobre a regulamentação da Internet no Brasil e no mundo. É necessário que esse dilema receba no país a importância devida pelos agentes que se engajam no debate, considerando as implicações sobre interesse público e a necessidade de se preservar a neutralidade da rede.

Como conclusão, pode-se afirmar que a relevância do tema transcende em muito o simples deslinde do episódio judicial que precipitou a discussão, transformando uma questão particular em um intrincado caso de restrição aos direitos de acesso ao conhecimento, educação e entretenimento. Se toda imagem está fadada à ampliação, espera-se que destino em nada menor seja reservado ao debate aqui esboçado.

\section{Referências}

\section{Bibliográficas}

BERNES-LEE, Tim. Weaving the web: the original design and ultimate destiny of the World Wide Web by its inventor. New York: HarperCollins, 1999.

CASIMIRO, Sofia de Vasconcelos. A responsabilidade civil pelo conteúdo da informação transmitida pela Internet. Coimbra: Almedina, 2000.

DI PIETRO, Maria Sylvia Zanella. Parcerias na administração pública. 5. ed. São Paulo: Atlas, 2005.

GIORGIANNI, Michele. O direito privado e as suas atuais fronteiras. $R T$, São Paulo, v. 747.

LEMOS, Ronaldo. Direito, tecnologia e cultura. Rio de Janeiro: Editora FGV, 2005.

MARTINS-COSTA, Judith. Os direitos fundamentais e a opção culturalista do novo Código Civil. In: SARLET, Ingo Wolfgang (Org.). Constituição, direitos fundamentais e direito privado. Porto Alegre: Livraria do Advogado, 2003.

NEGREIROS, Teresa. Teoria do contrato. Rio de Janeiro: Renovar, 2002. p. 67.

PEREIRA, Jane Reis Gonçalves. Apontamentos sobre a aplicação das normas de direito fundamental nas relaçōes jurídicas entre particulares. In: BARROSO, Luis Roberto (Org.). A nova interpretą̧ão constitucional: ponderação, direitos fundamentais e relações privadas. Rio de Janeiro: Renovar, 2003.

49 Ronaldo Lemos. Direito, tecnologia e cultura. Rio de Janeiro: Editora FGV, 2005. p. 125. 
PEREIRA, Jane Reis Gonçalves. Direitos fundamentais e interpretação constitucional: uma contribuição ao estudo dos limites e restrições aos direitos fundamentais na perspectiva da teoria dos princípios. Tese de doutorado defendida na UERJ, 2004, sob orientação de duas R. Barroso.

SARMENTO, Daniel. A vinculação dos particulares aos direitos fundamentais no direito comparado e no Brasil. In: BARROSO, Luis Roberto (Org.). A nova interpretação constitucional: ponderação, direitos fundamentais e relações privadas. Rio de Janeiro: Renovar, 2003.

SILVA, Luís Virgílio Afonso da. Interpretação e aplicą̧ão da constituição: fundamentos de uma dogmática constitucional transformadora. 5. ed. Rio de Janeiro: Saraiva, 2003.

O proporcional e o razoável. $R T$, v. 798 .

TEPEDINO, Gustavo. Editorial. Revista Trimestral de Direito Civil, Rio de Janeiro: Padma, v. 14, abr./jun. 2003.

UBILLOS, Juan María Bilbao. ¿En qué medida vinculan a los particulares los derechos fundamentales?". In: SARLET, Ingo Wolfgang (Org.). Constituição, direitos fundamentais e direito privado. Porto Alegre: Livraria do Advogado, 2003.

\section{Jurisprudenciais}

TJSP, Agr. 472738-4; rel. Des. Ênio Santarelli Zuliani; j. em 28.9.2006.

STJ, REsp no 595600/SC; rel. Min. Cesar Asfor Rocha; j. em 18.3.2004.

\section{Internet}

BBC BRASIL: Disputa entre YouTube e Cicarelli repercute no exterior. Disponível em: <http://www.estadao.com.br/arteelazer/variedades/noticias/2007/jan/05/ $297 \mathrm{htm}>$.

BRASIL TELECOM. Censura a internet no Brasil bloqueando acesso ao YouTube. Disponível em: <http://www.softwarelivre.org/news/8219>.

CONSULTOR JURÍDICO: O namoro do ano - Justiça confirma veto ao vídeo de Cicarelli na Internet. Disponível em: <http://conjur.estadao.com.br/static/ text $/ 48727,1>$.

EDELMAN, Benjamin; ZITTRAIN, Jonahan: Documentation of Internet filtering worldwide. Disponível em: <http://cyber.law.harvard.edu/filtering/>.

$<$ http://www.channels.nl/amsterdam/annefran.html > .

<http://www.foxsearchlight.com/index.php>. 
<http://idgnow.uol.com.br/internet/2007/01/10/idgnoticia.2007-0110.8286737443/IDGNoticia_view>.

$<$ http://www.rollingstone.com/ $>$.

. Brasil Telecom e Telefônica liberam acesso ao YouTube no Brasil. Disponível em: < http://idgnow.uol.com.br/internet/2007/01/09/idgnoticia.2007-0109.5384975768/IDGNoticia_view>.

IDGNOW!:Justiça deSP nega que mandou tirar YouTube doar. Disponível em: < http:// idgnow.uol.com.br/internet/2007/01/04/idgnoticia.2007-01-04.0064595137/ IDGNoticia_view $>$.

LEIA a íntegra da medida que manda desbloquear o YouTube no Brasil. Disponivel em: <http://idgnow.uol.com.br/internet/2007/01/09/idgnoticia.2007-0109.7954769479/IDGNoticia_view $>$.

UOL. Brasil Telecom e Telefonica bloqueiam acesso ao YouTube. Disponível em: <http://tecnologia.uol.com.br/ultnot/2007/01/09/ult4213u3.jhtm>. 